Check for updates

The BMJ

Cite this as: BMJ 2021;372:n399 http://dx.doi.org/10.1136/bmj.n399 Published: 10 February 2021

\section{Covid-19: Government wasted millions on poor quality PPE, spending watchdog finds}

\author{
Clare Dyer
}

The UK government wasted hundreds of millions of pounds of taxpayers' money on poor quality and unusable personal protective equipment (PPE) while leaving frontline workers insufficiently protected from covid-19, the parliamentary public spending watchdog has concluded. ${ }^{1}$

In a hard hitting report the House of Commons Public Accounts Committee painted a picture of an emergency scramble for PPE in which government contacts were handed contracts through a special channel without tender. But the "inadequate" pandemic plan left frontline workers "risking their own lives to provide treatment and care," the MPs' report said.

The report highlighted "the appalling situation of staff having to care for people with covid-19 or suspected covid-19 without sufficient PPE to protect themselves from infection."

The committee heard "compelling evidence from organisations representing frontline workers that stocks ran perilously low, single use items were reused, some was not fit for purpose-including reports of expired, substandard, deficient or even insect-infected supplies-and staff were in fear that they would run out."

Surveys by staff representative organisations found that at least $30 \%$ of care workers, doctors, and nurses reported having insufficient PPE, even in high risk situations. The committee accused the Department of Health and Social Care of knowing too little about the experience of frontline staff, particularly those from ethnic minorities. A third of Black and Asian doctors reported experiencing PPE shortages, compared with $14 \%$ of white doctors.

\section{Bypassing tender}

The decision to prioritise hospitals meant that social care providers were left exposed by the lack of PPE, the report said. Some 25000 patients were discharged to care homes from hospitals, some without being tested for covid-19, contributing significantly to deaths in care homes in the first wave. But while NHS trusts were provided with $80 \%$ of their estimated need for PPE, adult social care was given only $10 \%$ of its estimated need, the committee noted.

The government used emergency provisions allowing it to bypass the usual competitive tender when awarding contracts. A priority lane was set up for leads coming from government officials, ministers' offices, MPs, and members of the House of Lords. It was not clear why these leads were considered more credible than others, the committee said. The priority lane did not include organisations in the health and social care sector that had existing relations with suppliers.

The government has since built up an "enormous" amount of PPE, enough to last five years. The committee warned that this might compromise the government's ability to build up a UK manufacturing base for PPE because manufacturers would be unable to sell in the UK. It also outlined a range of recommendations to guard against repeating mistakes, including calling on the government to ensure that all the recommendations of the Boardman review, dealing with the procurement process and conflicts of interest, are implemented.

A non-profit campaigning organisation, the Good Law Project, along with a cross party group of three MPs, is taking the government to the High Court over its failure to publish contract details within the legally required timeframe.

Among the government deals highlighted are a contract with a jeweller worth $€ 70.5 \mathrm{~m}$ (€80.5m; $\$ 97.6 \mathrm{~m}$ ) to buy sterile gowns. Almost all of them cannot be used because the contract did not request the double packaging used in sterile settings. The government also signed contracts for millions of face masks, which were not usable in the NHS because they had the wrong type of fixing.

A Department of Health and Social Care spokesperson said, "As the Public Accounts Committee recognises, the government faced significant challenges in having to rapidly procure PPE at pace in a competitive international market. Thanks to the combined effort of the government, NHS, armed forces, civil servants, and industry we have delivered over 8.1 billion items of PPE at record speed.

"We have robust processes in place to ensure PPE meets the strictest safety and quality standards before being distributed to the front line."

House of Commons Public Accounts Committee. COVID-19: Government procurement and supply of personal protective equipment-42nd report of session 2019-21. Feb 2021. https://committees.parliament.uk/committee/127/public-accounts-committee/.

This article is made freely available for use in accordance with BMJ's website terms and conditions for the duration of the covid-19 pandemic or until otherwise determined by BMJ. You may use, download and print the article for any lawful, non-commercial purpose (including text and data mining) provided that all copyright notices and trade marks are retained. 